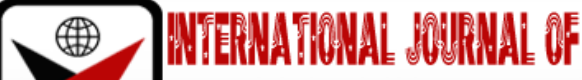

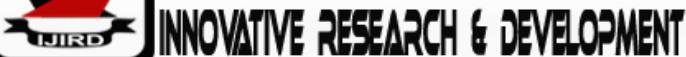

ISSN 2278-0211 (Online)

\section{Assessing the Drivers of Enhanced Auditors Performance: A Case Study in Public Universities in Kenya}

\author{
Ruth Mwende \\ Post Graduate Student, Department of Commerce, \\ Murang'a University of Technology, Kenya \\ Dennis Otieno \\ Lecturer, Department of Commerce, Murang'a University of Technology, Kenya
}

\begin{abstract}
:
The study evaluated the key drivers of enhanced auditor's performance in public universities in Kenya. The study posits that work environment, auditor's competence, independence and authority have not significant effects on their audit performance in public universities in Kenya. It used a descriptive case study to analyses the impact of the three variables on performance using Likert collected responses. The results showed that establishes that internal auditors working environment complying with professional standards is the most important contributor to internal auditing and formal auditing standards and its independence and authority positively influenced their auditing performance. performing auditing work according to internal auditing standards contributes significantly to the quality and effectiveness of auditing and finally that internal auditors evaluate and contribute to the improvement of risk management, control and governance using a systematic and disciplined approach in the public sector. To enhance auditor's performance and mitigate adverse corporate governance issues requires that the universities offer auditors independence and authority in the management protocols and establish internal audit unit to undertake periodical audits. To facilitate faster delivery of audit services including the detection and prevention of frauds and/or noncompliance with public expenditure management, the public universities to should provide a conducive work environment that enables the use of cutting edge ICT technology to support auditing functions, promote continuous training and develop institutional mechanisms (e.g., enforcement, auditing, or corporate governance structures) to encourage compliance with international standards.
\end{abstract}

Keywords: Auditor, independence, compliance, environment, Objectivity

\section{Background of the Study}

Internal auditors play a critical role in public expenditure management, information communication sharing and provides an assurance on institutional operations that enhance daily organizational performance (Reid \&Ashelby, 2002; Diamond, 2002; Institute of Internal Auditors (IIA), 2009). It safeguards organization resources and give an assessment of continuous resource use, feedback to public objectives and expectations, and, helps to reduce the risks inherent in the principal-agent relationship between the executive and the public ( Adel, 2011).

The basic roles of internal auditor's activities are directed towards evaluating compliance with the set rules and regulations in a bid to promote preciseness, efficient transactions and corrective actions against deficits for the purposes of transparency and accountability (Stoner, 1994; Owler\& Brown, 2009).

Internal auditors must be highly qualified in terms of skills, knowledge and objectivity. They are guided by institutional approved charters that spell out their authority, independence and scope of duty during the audit (Paape, 2007; IIA, 2004; Ramsay, 2002). Key factors such as management support, availability of working resources, independence of internal auditors and commitment by management significantly influence internal auditor's performance (Smithet al, 2001).

\subsection{Statement of the Problem}

Numerous complaints have been raised over the management of public funds and government being not as effective in detecting and preventing the misappropriation of public funds. Even after enacting Public Financial Management Act of 2012, cases of inefficiency in public resources management continue to be reported under frauds and corrupt practices (Diamond, 2002; Mihret\&Yismaw, 2007). The Auditor General noted that out of 101 financial reports for the fiscal year ended 30 June 2014, 26 had an unqualified opinion, 50 had a qualified opinion, 16 had an adverse opinion while 9 had a disclaimer of opinion. A number of studies equally carry similar reports key among them are Otieno (2010), who established that weak internal auditing procedures have increasingly become a major problem in detecting loss of public funds and are an indication of ineffectiveness of internal auditors in the public sector. This raises the question as to whether auditor related factors could be the weak link between auditing results and public institution performance. 
Answers to this question motivated this study to be carried in public universities in Kenya where there is scanty details concerning corruption cases and misappropriation of public funds in the public universities. We therefore sought to fill the existing information research gap to explain the drivers of internal auditor performance during audits in public universities in Kenya. The study tested that hypothesis that there are no significant effects that work environment, auditor's competence, independence and authority have not significant effects on their audit performance in public universities in Kenya.

\subsection{Conceptual Framework}

A conceptual framework is based on stakeholder theory, agency theory and contingency theory and envisages a are correlation between the auditors work environment, independence and competence as the key factors influencing auditor's contribution to performance in auditing tasks.

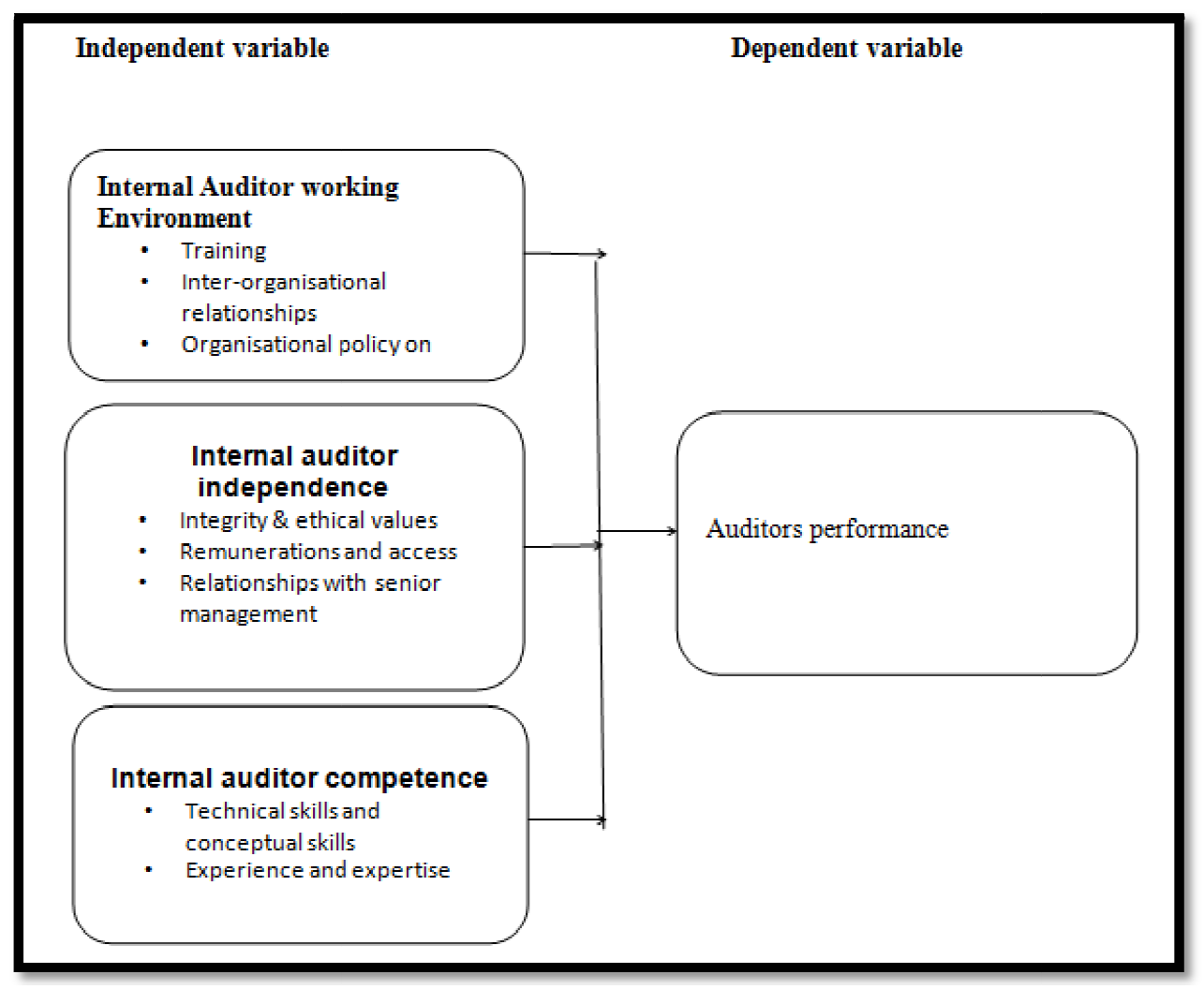

Figure 1: Conceptual Framework

\section{Research Methodology}

This descriptive case study involved 31 chartered public universities in Kenya which are registered by the Higher Education ministry (CUE). Participation was based on the ability of the university to respond based on a phone call. Data collection procedure observed all the necessary ethical consideration like explaining the purpose of the study, assuring the respondents of confidentiality.

Data was analyzed using the following regression model:

$Y=\beta_{0}+\beta_{1} X_{1}+\beta_{2} X_{2}+\beta_{3} X_{3}+\varepsilon$

Where:

$\mathrm{Y}=$ Internal Auditor performance,

$\beta 0=$ Constant Term,

$\beta 1=$ Beta coefficients

$\mathrm{X}_{1}=$ working environment,

$\mathrm{X}_{2}=$ Auditors independence,

$\mathrm{X}_{3}=$ internal auditors' competence,

$\varepsilon=$ Error Term

\subsection{Response Rate}

The response rate was a high (99\%) with $73 \%$ of the respondents being males. All of them had post-secondary school level education and were professional member of CPAKs. The respondent's length of service in the public universities shows that $74 \%$ had over 6 years of service at the university level. 


\section{Number of years in Service}

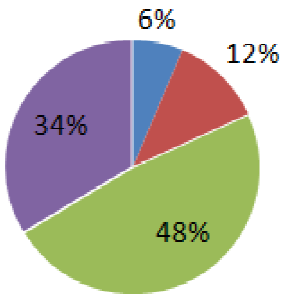

nunder2 years

a 3 to 5 years

$\square$ to 10 years

Q over10 Years

Figure 2: Years of Schooling

\subsection{CorrelationAnalysis}

Data on auditors performance, work environment, competence, independence and authority was analyzed at their means and the subjected to correlation analysis to identify the variables that could be used in the final regression. The results showed that all variables could be used in regression due to the high level correlation with the dependent variable and low correlation among themselves.

\begin{tabular}{|c|c|c|c|c|}
\hline & $\mathbf{Y}$ & $\mathbf{X 1}$ & $\mathbf{X} 2$ & $\mathbf{X 3}$ \\
\hline $\mathrm{Y}$ & 1 & & & \\
\hline $\mathrm{X} 1$ & $0.807^{* *}$ & 1 & & \\
\hline $\mathrm{X} 2$ & $0.793^{* *}$ & $0.480^{* *}$ & 1 & 1 \\
\hline $\mathrm{X} 3$ & $0.749^{* *}$ & $0.452^{* *}$ & $0.443^{* *}$ & \\
\hline \multicolumn{4}{|c|}{. Correlation is significant at the 0.01 level (2-tailed). } \\
\hline
\end{tabular}

$\mathrm{Y}=$ Internal Auditor performance, $\beta_{0}=$ Constant Term, $\beta_{1}=$ Beta coefficients, $\mathrm{X} 1=$ working environment, $\mathrm{X} 2=$ Auditor's independence, X3 = internal auditors' competence

From table 4.10 it can be observed that the correlation between the independent variables and the dependent variable was high and positive at $0.807,0.793$ and 0.749 for working environment, internal auditor independence and internal auditor competence. The interpretation was that the level of multi-collinearity between the independent variable was low though significant, which meant that the influence of each variable in the regression model could be identified without challenges. Burns and Burns (2008), note that multi-collinearity is the presence of high correlations between the independent variables and should be avoided or minimized. The variables were found to have a strong positive effect on auditors' performance. The interpretation was that improved working environment, adequate internal Auditor independence and high competence would lead to improved performance of the internal Auditor.

\subsection{Regression Result}

\begin{tabular}{|c|c|c|c|}
\hline $\mathbf{R}$ & $\mathbf{R}^{\mathbf{2}}$ & Adjusted R Square & Std. Error of the Estimate \\
\hline 0.893 & 0.797 & 0.789 & 0.45886784 \\
\hline
\end{tabular}

Table 2: Model Summary

From table 4.11 the values of the results were R0.807, R Square0.652 and adjusted R square 0.647. These values clearly suggest that there is a strong relationship between, working environment and performance of internal auditor for this model. This indicates that working environment had a statistically significant effect on performance of internal auditor.

\begin{tabular}{|c|c|c|c|c|c|}
\hline & $\begin{array}{c}\text { Sum of } \\
\text { Squares }\end{array}$ & df & $\begin{array}{c}\text { Mean } \\
\text { Square }\end{array}$ & F & Sig. \\
\hline Regression & 52.779 & 1 & 52.779 & 149.618 & 0 \\
\hline Residual & 28.221 & 80 & 0.353 & & \\
\hline Total & 81 & 81 & & & \\
\hline
\end{tabular}

The F-statistic was found to be 149.618 and was significant showing that the independent variables were significantly different and that each could contribute differently to the performance of the auditors. The contribution of these variables to the overall performance under interaction is given in the Table below. . 


\begin{tabular}{|c|c|c|c|c|}
\hline Variable & Coefficients & Std. Error & t-statistic & p-value \\
\hline (Constant) & 0.15 & 0.051 & 2.915 & 0.005 \\
\hline Working environment & 0.383 & 0.073 & 5.231 & 0 \\
\hline Internal auditor independence & 0.353 & 0.074 & 4.773 & 0 \\
\hline Internal auditor competence & 0.258 & 0.07 & 3.663 & 0 \\
\hline
\end{tabular}

The study model provided useful insight on the relationship between auditor's performance and the three variables namely auditor's independence and authority, competence and work environment Table 1, Table 2 and Table 3. The model results also showed a good fit of $65.3 \%$ with all the said variables having a significant effect of auditor's performance. This is in line with earlier studies by which accepted similar hypothesis. This high coefficient of determination is comparable with the results from earlier studies that used structural equation modelling. This reveals that goodness of fit for the model and the proxies used for auditors role imply that audits success are incumbent on internal auditors working environment, compliance with professional standards, providing auditor's objectivity and compliance with accepted criteria for professional practice and standards for audits.

All the variables significantly enhance auditor's performance in public universities in Kenya. Work environment is the main driver of success followed by internal auditor's independence and finally internal auditor's competence.

This results, Table 4 show that when conditions in the work environment is improved by $1 \%$, auditors are enhanced by $0.383 \%$ measure. Similarly, a 1\% improvement in auditors independence and competence will lead to a 0.353 and 0.258 percentage increases respectively. These increases are both significant at $90 \%$ confidence interval. Although the coefficient of determination is $65.2 \%$, the regression constant is significant implying that not all relevant variables have been included in the study.

Work environment was the most important driver of improved performance. Earlier studies had shown that conducive work environment leads to job satisfaction and organization commitment. Job satisfaction and organizational commitment encourage internal auditors to show organizational citizenship behavior in achieving organization goals (Pitaloka and Sofia, 2014). The finding coincides with Morgan (2009) that performance is negatively impacted in organizations where internal auditors work under poor working conditions and where management fails to support their role and despise them as unworthy in the organization and fail to allocate sufficient resources to the internal audit function.

Competence was another driver of auditor's good performance at the local universities. It encompassed organization management and operation research skills, higher-level objectives link with universities operational objectives, the universities attitude towards identified risks, the universities key related risks and how they impact their high-level objectives, risk, control tools and techniques, project management, electronic work papers, process modelling software and understanding performance and measurement principles verses output targets designed to deliver objectives.

Competent auditor's comply with international auditing standards are bound to be successful in their work. Compliance with internal auditing standards contributes significantly to the quality and effectiveness of auditing and finally that internal auditors evaluate and contribute to the improvement of risk management, control and governance using a systematic and disciplined approach in the public sector.

Enhanced auditor's independence and authority requires that the management of the public institution give a free hand to auditors to evaluate institutional activities freely (Zayol and Kukeng 2017). This ensures that quality Kukang audit reports are prepared just like the systems that prepare them. Therefore, public universities must be prepared to provide conducive work environment that gives independence to auditors and their authority to ensure objectivity in audit reports. Embracing auditor'sindependence significantly impact on their performance in the public sector. Effective auditing standards influence auditor's behavior and improve the quality and effectiveness of audits by substantially adjusting audit practice

\section{Conclusion and Policy Recommendation}

The study concludes that the auditor's performance is positively influenced by internal auditors working environment, auditors independence and authority in that the management policy establishes internal audit unit and the universities. To enhance auditors performance it is important to mitigate adverse corporate governance issues requires that the universities offered auditors independence and authority in that the management policy establishes internal audit unit and the universities does not permit internal auditors to audit operations which they have undertaken. It is also important for the public universities to facilitate faster delivery of services including the detection and prevention of frauds and/or non-compliance with public expenditure management, by providing a conducive work environment that enables the use of cutting edge ICT technology to support auditing functions, promote continuous training and develop institutional mechanisms (e.g., enforcement, auditing, or corporate governance structures) to encourage compliance with international standards.

\section{References}

i. Adel S. M. (2011). Internal audit effectiveness: an expansion of present methods, Managerial Auditing Journal, 16(8):89-112.

ii. Brown, P. R. (2013). Independent auditor judgment in the evaluation of internal audit functions. Journal of Accounting Research, 21(2):444-455. 
iii. $\quad$ Burns,R.B. and Burns, R.A. (2008).Business research methods and statistical using SPSS. SAGE Publications Ltd, London.

iv. Diamond, M. J. (2002). The role of internal audit in government financial management: Aninternational perspective. International Monetary Fund, Number. 2-94.

v. IIA, (2012). The standards for the professional practice of internal auditing. Altamonte Springs: The Institute of Internal Auditors, Research Foundation.

vi. Mihret, D. G., \&Yismaw, A. W. (2011). Internal audit effectiveness: An Ethiopian public sector case study. Managerial Auditing, Journal, 22(5), 470-484

vii. Otieno, S. (2012). Members Lose KShs 60 Million As Kisumu Sacco Collapses. The Star newspaper (2012, March 28th)

viii. Owler L. \& Brown J. L. (2009). Cost and Management, Accounting Methods Macdonald \& Evans Press London pp.39

ix. Paape, L. (2011). Corporate governance: The impact on the role, position, and scope of services of the internal audit function. Unpublished PhD dissertation Erasmus Research Institute of Management Erasmus University, Netherlands.

x. Pitaloka N, and Sofia I.P. (2014). The effects of Work environment job satisfaction and organizational commitment on OCB of internal Auditors.

xi. $\quad$ https://www.researchgate.net/publication/304550892_

xii. Ramsay, I. (2002). Independence of Australian Company Auditors: A Review of Current Australian Requirements and Proposals for Reform, October 2002.

xiii. Reid, K. \&Ashelby, D. (2002). The Swansea internal quality audit processes quality assurance in education. Vol. 10 ,

xiv. Rick Hayes et al. (2005). Principles of auditing Pearson Education Limited. SAP. Enterprise Smith, M. Normah, Zulkarnain\&Ithnahaini (2001). Auditors' perception of fraud risk indicators: Malaysian evidence. Managerial Auditing Journal, 20(1):73-85.

xv. Stoner A. F. (1994). Management. New Jersey: Practice Hall Inc. Company

xvi. Zayol P.I., And Kukeng V. (2017). Effect of auditor independence on audit quality: a review of literature. International journal of Business and Management invention ISSN (online): 2319 - 8028, ISSN (print): 2319 801x www.ijbmi.org // volume 6 issue 3 // march. 2017 |/ pp-51-59 www.ijbmi.org 51 | page 